\title{
Harpins, Multifunctional Proteins Secreted by Gram-Negative Plant-Pathogenic Bacteria
}

\author{
Min-Seon Choi, ${ }^{1}$ Wooki Kim, ${ }^{2}$ Chanhui Lee, ${ }^{3}$ and Chang-Sik Oh ${ }^{1}$ \\ ${ }^{1}$ Department of Horticultural Biotechnology, ${ }^{2}$ Department of Food Science and Biotechnology, and ${ }^{3}$ Department of Plant and \\ Environmental New Resources, Kyung Hee University, Yongin, 446-701, Korea
}

Submitted 15 February 2013. Accepted 28 May 2013.

\begin{abstract}
Harpins are glycine-rich and heat-stable proteins that are secreted through type III secretion system in gram-negative plant-pathogenic bacteria. Many studies show that these proteins are mostly targeted to the extracellular space of plant tissues, unlike bacterial effector proteins that act inside the plant cells. Over the two decades since the first harpin of pathogen origin, HrpN of Erwinia amylovora, was reported in 1992 as a cell-free elicitor of hypersensitive response (HR), diverse functional aspects of harpins have been determined. Some harpins were shown to have virulence activity, probably because of their involvement in the translocation of effector proteins into plant cytoplasm. Based on this function, harpins are now considered to be translocators. Their abilities of pore formation in the artificial membrane, binding to lipid components, and oligomerization are consistent with this idea. When harpins are applied to plants directly or expressed in plant cells, these proteins trigger diverse beneficial responses such as induction of defense responses against diverse pathogens and insects and enhancement of plant growth. Therefore, in this review, we will summarize the functions of harpins as virulence factors (or translocators) of bacterial pathogens, elicitors of $\mathrm{HR}$ and immune responses, and plant growth enhancers.
\end{abstract}

Gram-negative plant-pathogenic bacteria use a sophisticated system to secrete proteins during interaction with host plants to cause diseases, as do animal-pathogenic bacteria (Grant et al. 2006). This is called the type III secretion system (T3SS), of which structural proteins are encoded by hypersensitive response and pathogenicity ( $h r p$ ) genes (Tampakaki et al. 2010). The nine hrp genes that are highly conserved among pathogenic bacteria were renamed $h r p$-conserved $(h r c)$ genes (Bogdanove et al. 1996a). These Hrp and Hrc proteins are assembled to form the T3SS machinery (Jin and He 2001; Li et al. 2002; Roine et al. 1997).

In addition to encoding structural proteins for an Hrp pilus and T3SS regulatory proteins, some hrp genes encode two types of secreted proteins: i) effector proteins that are delivered into plant cells and ii) extracellular accessary proteins including harpins (Alfano and Collmer 2004). Effector proteins as virulence factors are known to suppress diverse signaling pathways necessary for plant innate immunity. In certain plant species or

Corresponding author: C.-S. Oh; Telephone: +82-31-201-2678; E-mail: co35@khu.ac.kr

(C) 2013 The American Phytopathological Society cultivars, effector proteins can be recognized by corresponding disease resistance $(\mathrm{R})$ proteins and induce the hypersensitive response (HR) as a potent resistance mechanism in plants (Eitas and Dangl 2010). The HR is a rapid cell death at the infection sites and a type of programmed cell death in plants. The functions of harpins are not well understood, although they were found two decades ago as cell-free HR elicitors originated from bacterial pathogens (Wei et al. 1992). In the last 10 years, there has been significant progress to elucidate the mechanism of their virulence functions as translocators or helper proteins of effector proteins at the host plasma membranes. In this review, we will summarize what has been found about harpins and also what will be needed for further elucidation of harpin functions in bacterial pathogen-plant interactions.

General characteristics of harpins.

Since the first harpin, HrpN of Erwinia amylovora, was characterized as the first pathogen independent HR elicitor in plants (Wei et al. 1992), several other harpins have been characterized from diverse gram-negative plant-pathogenic bacteria (Table 1); for example, HrpN and HrpW of Erwinia spp. and related bacteria (Bauer et al. 1995; Gaudriault et al. 1998; Kim and Beer 1998; Shrestha et al. 2008), HrpZ1 (originally HrpZ), HrpW1 (originally HrpW), HopP1, and HopAK1 of Pseudomonas syringae (Charkowski et al. 1998; He et al. 1993; Kvitko et al. 2007), PopA1 and PopW of Ralstonia solanacearum (Arlat et al. 1994; Li et al. 2010), and Hpa1 and its orthologs of Xanthomonas spp. (Kim et al. 2003; Noel et al. 2002; Zhu et al. 2000). These harpins can be categorized into four major groups based on their protein similarity and domain structures (Table 1).

Harpins are unique proteins that share common characteristics, which are distinct from other bacterial proteins. First, in terms of amino acid composition in harpins, they carry a relatively high amount of glycine and serine residues (Table 1), whereas they carry no or few cysteine and few aromatic amino acids. Most harpins consist of greater than $15 \%$ glycine, and these are often clustered in specific regions of these proteins (Fig. 1). In the case of HopAK1, XopA, and $\mathrm{Hpa}_{\mathrm{Xm}}$, their glycine ratio is relatively lower than those of other harpins. The amino acid serine covers approximately $10 \%$ of total amino acids of harpins. Interestingly, most harpins have no cysteines, which contribute to disulfide bonding. Presumably, this is the reason that attempts at structure prediction of the E. amylovora HrpN have failed (S. V. Beer, personal communication). However, Hpal carries one cysteine and $\mathrm{Hpa}_{\mathrm{Xm}}$ carries four cysteines. Second, in terms of secondary structures, harpins are predicted to have several regions of $\alpha$-helices (Fig. 1). HrpN of 
E. amylovora and HrpZ1 of $P$. syringae carry eight or nine $\alpha$ helices, and HrpW of E. amylovora carries two $\alpha$-helices only at the N-terminal domain. Third, harpins are very acidic, based on their theoretical isoelectric points, with the exception of HopAK1 and $\mathrm{Hpa}_{\mathrm{Xm}}$ (Table 1). Fourth, the sizes of harpins from Xanthomonas spp. are significantly smaller than those from Erwinia- and Pseudomonas-related bacteria (Table 1). Finally, harpins are heat stable, probably due to the lack of obvious tertiary structures stabilized by cysteine bridges as described above. However, this characteristic has made it relatively easy to purify harpins to produce cell-free elicitor preparation, because the HR elicitor activity of harpins remains active even after boiling for $15 \mathrm{~min}$ (He et al. 1993; Wei et al. 1992).

Most harpins do not carry any domains found in other bacterial or plant proteins. However, HrpW orthologs (E. amylovora HrpW, P. syringae HrpW1 and HopAK1, and R. solanacearum PopW) carry pectate lyase domains in their C termini (Charkowski et al. 1998; Kim and Beer 1998; Li et al. 2010). Because of this, they are considered to be two domain proteins unlike the other harpin groups. The $\mathrm{N}$-terminal domains of HrpW-group harpins were shown to be responsible for HR elicitation (Charkowski et al. 1998; Kim and Beer, 1998). However, although HrpW1 and PopW specifically were shown to bind to calcium pectate, no pectate lyase activity was detectable in any of these harpins in vitro (Charkowski et al. 1998; Li et al. 2010). Interestingly, a symbiotic bacterium, Rhizobium etli, also produces a HrpW homolog, and this protein exhibits pectate lyase activity (Fauvart et al. 2009). Based on sequence alignment, Trp-192 of HrpW of $R$. etli was conserved in all active pectate lyase enzymes but not in $\mathrm{HrpW}$ of $E$. amylovora and HrpW1 of $P$. syringae. More importantly, site-directed mutagenesis confirmed that Trp-192 was critical for detectable pectate lyase activity of $\mathrm{HrpW}$ of $R$. etli. This amino acid difference may explain why HrpW harpins from phytopathogenic bacteria do not possess obvious pectate lyase activity.

\section{Harpins as virulence factors of bacterial pathogens.}

Expression of harpin genes is tightly controlled by Hrp regulatory proteins, and they are highly expressed during infection of plants or in apoplast-mimicking medium (Bogdanove et al. 1996b; Fouts et al. 2002; Wei and Beer 1995), indicating that harpins do play a role in the interaction with plants. Based on mutational analysis, some harpins have been reported to have virulence functions in host plants. Mutation of the $h r p N$ gene by transposon insertion in E. amylovora strain CFBP1430 isolated from hawthorn reduced virulence but this mutant still retained significant virulence in host plants (Barny 1995). However, the mutant, in which hrpN gene had been deleted from E. amylovora strain Ea273 (ATCC 49946), blighted less than 3\% of apple shoot length compared with $80 \%$ blighted by the wild-type strain and also did not trigger disease symptoms on immature pear fruits (Sinn et al. 2008). Deletion of the hrpN gene in Dickeya dadantii (previously named $E$. chrysanthemi) also showed reduced virulence in African violet leaves (Yang et al. 2002).

Table 1. List of harpin proteins functionally characterized in gram-negative plant-pathogenic bacteria

\begin{tabular}{|c|c|c|c|c|c|c|c|c|c|c|c|}
\hline \multirow[b]{2}{*}{ Names $^{a}$} & \multirow[b]{2}{*}{ Source bacteria } & \multicolumn{4}{|c|}{ Protein features } & \multicolumn{3}{|c|}{$\begin{array}{c}\text { Bacterial } \\
\text { virulence-related features }\end{array}$} & \multicolumn{3}{|c|}{$\begin{array}{c}\text { Functional } \\
\text { features in plants }\end{array}$} \\
\hline & & $N^{\mathbf{b}}$ & Glycine (\%) & Serine (\%) & $\mathbf{p I}^{\mathbf{c}}$ & Severity $^{d}$ & Effector $^{\mathrm{e}}$ & Lipid $^{f}$ & HR $^{\mathrm{g}}$ & Defense $^{h}$ & Growth $^{\mathrm{i}}$ \\
\hline \multicolumn{12}{|c|}{ HrpN group } \\
\hline $\mathrm{HrpN}$ & Erwinia amylovora & 403 & 22.6 & 10.2 & 4.59 & + & + & + & + & + & + \\
\hline $\mathrm{HrpN}$ & E. pyrifoliae & 428 & 25.9 & 11.0 & 4.64 & $\ldots$ & $\ldots$ & $\ldots$ & $\ldots$ & $\ldots$ & $\ldots$ \\
\hline $\mathrm{HrpN}$ & Dickeya dadantii (E. chrysanthemi) & 340 & 16.2 & 11.8 & 6.42 & $\ldots$ & $\ldots$ & $\ldots$ & $\ldots$ & $\ldots$ & $\ldots$ \\
\hline HrpN & E. carotovora subsp. carotovora & 356 & 21.3 & 11.2 & 5.24 & $\ldots$ & $\ldots$ & $\ldots$ & $\ldots$ & $\ldots$ & $\ldots$ \\
\hline \multicolumn{12}{|c|}{ HrpZ1 group } \\
\hline HrpZ1 & Pseudomonas syringae pv. tomato & 370 & 15.7 & 11.6 & 4.06 & ND & + & + & + & + & + \\
\hline HrpZ & P. syringae pv. phaseolicola & 345 & 12.8 & 10.1 & 4.21 & $\ldots$ & $\ldots$ & $\ldots$ & $\ldots$ & $\ldots$ & $\ldots$ \\
\hline HrpZ & P. syringae pv. syringae & 341 & 13.2 & 10.0 & 4.16 & $\ldots$ & $\ldots$ & $\ldots$ & $\ldots$ & $\ldots$ & $\ldots$ \\
\hline HrpZ & P. syringae pv. glycinea & 345 & 12.8 & 9.9 & 4.21 & $\ldots$ & $\ldots$ & $\ldots$ & $\ldots$ & $\ldots$ & $\ldots$ \\
\hline $\mathrm{HrpZ}^{\mathrm{j}}$ & P. syringae pv. tabaci & 140 & 8.6 & 10.0 & 4.85 & $\ldots$ & $\ldots$ & $\ldots$ & $\ldots$ & $\ldots$ & $\ldots$ \\
\hline \multicolumn{12}{|c|}{ HrpW1 group } \\
\hline HrpW1 & P. syringae pv. tomato & 424 & 15.3 & 7.1 & 4.63 & - & + & ND & + & + & ND \\
\hline HrpW & E. amylovora & 447 & 14.3 & 11.9 & 4.66 & $\ldots$ & $\ldots$ & $\ldots$ & $\ldots$ & $\ldots$ & $\ldots$ \\
\hline PopW & Ralstonia solanacearum & 380 & 12.4 & 8.4 & 6.17 & $\ldots$ & $\ldots$ & $\ldots$ & $\ldots$ & $\ldots$ & $\ldots$ \\
\hline HopAK1 & P. syringae pv. tomato & 555 & 7.7 & 10.8 & 7.2 & $\ldots$ & $\ldots$ & $\ldots$ & $\ldots$ & $\ldots$ & $\ldots$ \\
\hline $\mathrm{HrpW}^{\mathrm{k}}$ & Rhizobium etli & 304 & 10.5 & 8.9 & 4.54 & $\ldots$ & $\ldots$ & $\ldots$ & $\ldots$ & $\ldots$ & $\ldots$ \\
\hline \multicolumn{12}{|c|}{ Hpa1 group } \\
\hline Hpa1 & Xanthomonas oryzae pv. oryzae & 139 (1 Cys) & 24.5 & 11.5 & 4.07 & + & ND & + & + & + & + \\
\hline Hpa1 & $X$. oryzae pv. oryzicola & 137 (1 Cys) & 21.2 & 13.9 & 4.06 & $\ldots$ & $\ldots$ & $\ldots$ & $\ldots$ & $\ldots$ & $\ldots$ \\
\hline Hpa1 & $X$. axonopodis pv. citri & 137 & 22.6 & 11.7 & 3.85 & $\ldots$ & $\ldots$ & $\ldots$ & $\ldots$ & $\ldots$ & $\ldots$ \\
\hline HpaG & $X$. axonopodis pv. glycines & 133 & 21.1 & 10.5 & 3.85 & $\ldots$ & $\ldots$ & $\ldots$ & $\ldots$ & $\ldots$ & $\ldots$ \\
\hline XopA & $X$ campestris pv. vesicatoria & 117 & 8.5 & 13.7 & 4.1 & $\ldots$ & $\ldots$ & $\ldots$ & $\ldots$ & $\ldots$ & $\ldots$ \\
\hline HreX & $X$. campestris pv. pelargonii & 114 (1 Cys) & 15.8 & 11.4 & 3.54 & $\ldots$ & $\ldots$ & $\ldots$ & $\ldots$ & $\ldots$ & $\ldots$ \\
\hline \multicolumn{12}{|l|}{ Others } \\
\hline PopA1 & Ralstonia solanacearum & 344 & 20.9 & 6.7 & 4.38 & ND & ND & + & + & + & ND \\
\hline HopP1 & P. syringae pv. tomato & 324 & 15.4 & 12.7 & 4.33 & ND & + & ND & + & ND & ND \\
\hline $\mathrm{Hpa}_{\mathrm{Xm}}$ & $X$. citri subsp. malvacearum & 187 (4 Cys) & 8.6 & 8.0 & 9.96 & ND & ND & ND & + & ND & ND \\
\hline
\end{tabular}

${ }^{\mathrm{a}}$ Harpin group and original harpin names.

${ }^{\mathrm{b}}$ Number of total amino acids.

c $\mathrm{pI}=$ isoelectric point.

${ }^{\mathrm{d}}$ Bacterial growth or disease severity; ND = not determined.

e Effector translocation.

${ }^{\mathrm{f}}$ Pore formation or lipid binding.

${ }^{g}$ Hypersensitive response (HR) cell death in tobacco.

${ }^{\mathrm{h}}$ Defense induction.

${ }^{i}$ Plant growth promotion.

j Nonfunctional truncated protein.

${ }^{\mathrm{k}}$ No effect on symbiosis. 
In addition to $h r p N$, mutation of hpal or its orthologs in Xanthomonas spp. by deletion or transposon insertion resulted in reduced symptoms and bacterial growth in their host plants (Kim et al. 2003; Noel et al. 2002; Sgro et al. 2012; Zhu et al. 2000). In contrast, the hrpW mutation in E. amylovora or pop $W$ mutation in $R$. solanacearum did not show any effect on virulence on host plants (Gaudriault et al. 1998; Kim and Beer 1998; Li et al. 2010). These indicate that harpins belonging to $\mathrm{HrpN}$ and $\mathrm{Hpa} 1$ groups carry virulence activity in plants.

\section{Harpins as a part of translocator complexes for effector translocation into plant cells.}

In terms of underlying mechanisms by which the contribution of harpins to virulence might be explained, there is significant evidence that harpins act as translocators facilitating the injection of bacterial effector proteins into plant cells. $\mathrm{DspA} / \mathrm{E}$ is a critical effector of E. amylovora for disease development, and its translocation into host cells was severely impaired in the E. amylovora $h r p N$ mutant, as determined by CyaA activity fused with DspA/E (Bocsanczy et al. 2008). AvrPto is a well-characterized effector of $P$. syringae pv. tomato, and it acts as a virulence factor by inhibiting plant innate immunity (Zipfel and Rathjen 2008). The same CyaA reporter assays showed that a hrpKl quadruple harpin polymutant of
$P$. syringae pv. tomato, in which hrpKl and the four harpin genes $h r p Z 1, h r p W 1$, hopPl, and hopAKl were deleted, dramatically reduced translocation of AvrPto-CyaA but not its secretion in culture (Kvitko et al. 2007). Interestingly, HrpK1, HrpZ1, HrpW1, or HopAK1 but not HopP1 could complement the hrpK1 quadruple harpin polymutant in a certain level. In $P$. syringae, HrpK1 was shown to act as a translocator to regulate effector translocation (Petnicki-Ocwieja et al. 2005). Interestingly, secretion of HrpK1 and the three harpins HrpZ1, HrpW1, and HopAK1 but not HopP1 was shown to be controlled by HrpJ (Crabill et al. 2012; Fu et al. 2006). Similarly, HrpN secretion was also impaired in an E. amylovora hrpJ mutant (Nissinen et al. 2007). This evidence suggests that secretion of harpins and HrpK1 through T3SS is coordinated by HrpJ and they may act together, forming a translocon for injecting effectors across the plant plasma membrane. In addition, harpins appear to act semiredundantly in translocation sense and this functional redundancy may explain why mutations in individual harpin genes mostly do not affect the virulence of bacterial pathogens in plants.

HopP1 of $P$. syringae carries the HrpW domain at its $\mathrm{N}$ terminus and the soluble lytic transglycosylase domain at its $\mathrm{C}$ terminus (Oh et al. 2007a). This protein was considered to be an atypical lytic transglycosylase like $\mathrm{HrpH}$ because they were
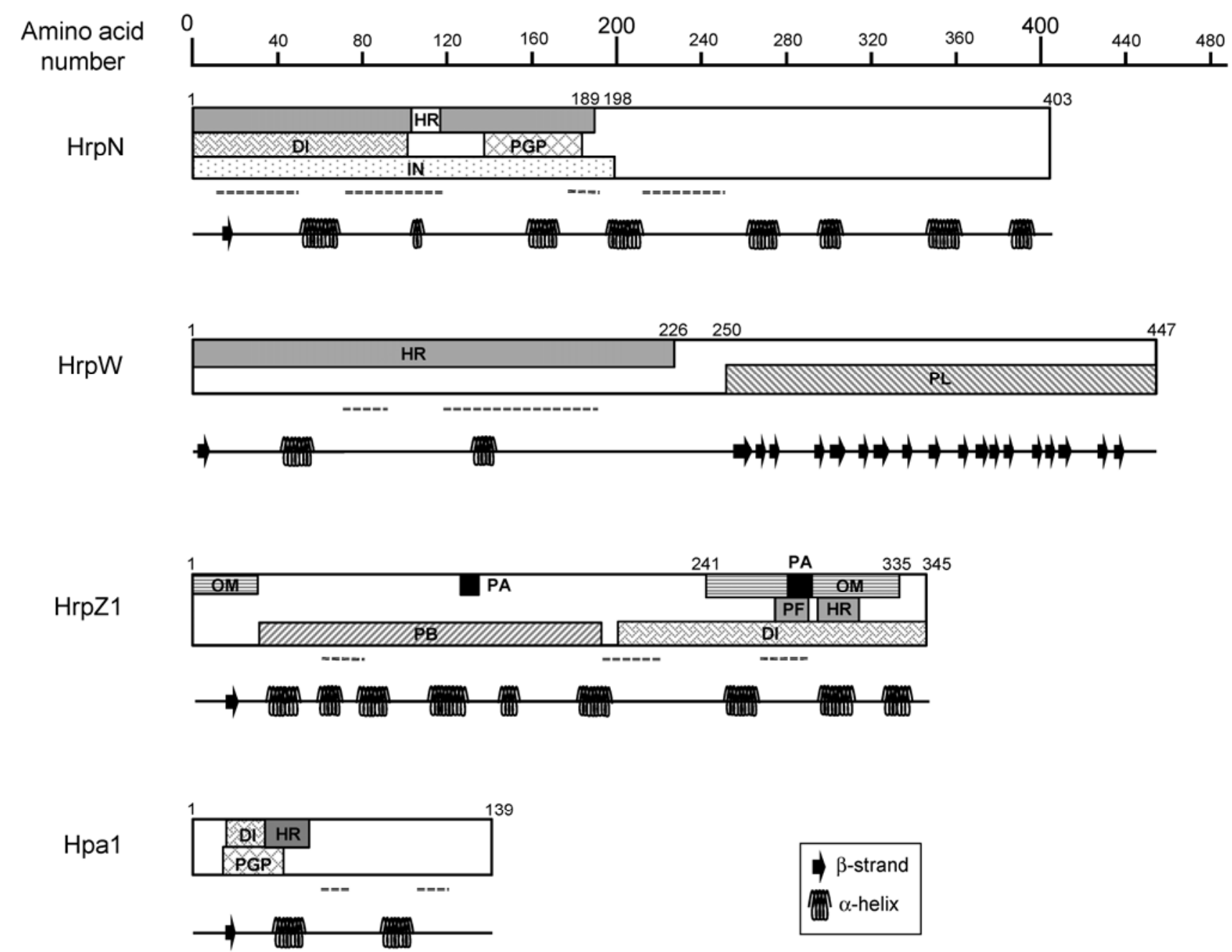

Fig. 1. Functional domain structures of Erwinia amylovora HrpN and HrpW, Pseudomonas syringae HrpZ1, and Xanthomonas oryzae Hpa1. Glycine-rich regions are shown at the bottom of each protein with the dotted line. The secondary structure of each harpin was predicted with the PSIPRED protein structure prediction server, as shown under each protein. Domains for each function were designated inside the protein. Abbreviations of each function are as follows. HR, hypersensitive response; IN, interaction with a host protein; PL, pectate lyase; OM, oligomerization; PA, phosphatidic acid binding; PB, peptide binding; DI, defense induction; PF, pore formation; PGP, plant growth promotion. 
shown to be translocated into plant cells, unlike other known lytic transglycosylases that act on peptidoglycan. Interestingly, in the $h r p H$ mutant, translocation of the effector protein HopA1 was severely impaired, and HopP1 expression could partially recover HopA 1 translocation in this mutant. However, HopP1 could not complement a $P$. syringae hrpK1 quadruple harpin polymutant (Kvitko et al. 2007). These indicate that HopP1 also plays a role in effector translocation; however, its role appears to be separate from other harpins such as HrpZ1, HrpW, and HopAK1. Consistent with HopP1 not playing a redundant role in translocation like that of HrpK1 and other harpins such as HrpZ1, HrpW, and HopAK1, secretion of HopP1 was not controlled by HrpJ (Crabill et al. 2012).

\section{Association of harpins with cell membranes.}

Association of harpins with the plant plasma membrane was shown by examining the ability of harpins to form pores in the artificial membranes, similar to the translocator proteins of animal-pathogenic bacteria (Neyt and Cornelis 1999); and, additionally, the ability of harpins to bind to lipids. HrpZ1 from $P$. syringae pv. phaseolicola was shown to be associated with liposomes and synthetic bilayer membranes in vitro by examining the presence of HrpZ1 proteins in purified liposomes after mixing with the recombinant HrpZ1 proteins (Lee et al. 2001b). HrpZ1 proteins from P. syringae pvs. phaseolicola, tomato, and syringae triggered ion-current fluctuation in the planar lipid bilayers. More directly, P. syringae HrpZ1, E. amylovora HrpN, and Xanthomonas campestris HreX were shown to be able to form pores in liposomes, and the intact HrpZ1 protein was required for pore formation (Engelhardt et al. 2009). In addition, a binding assay with 15 different membrane lipid components showed that HrpZ1 interacted with phosphatidic acid (Haapalainen et al. 2011). PopA1 from R. solanacearum was shown to be integrated into liposomes and also membranes from Xenopus laevis oocytes, resulting in the formation of ion-conducting pores (Racape et al. 2005). Moreover, this harpin showed a high affinity to sterols and sphingolipids in vitro. Collectively, these data show that several harpins can bind to lipids and form pores in the plant plasma membrane.

Translocator proteins in animal-pathogenic bacteria generally form a channel-like structure in the host plasma membrane by oligomerization (Montagner et al. 2011). Oligomerization of $P$. syringae HrpZ1 was examined by at least four different methods: gel filtration, chemical cross-linking, yeast twohybrid assay, and native gel analysis. All data from these assays showed that HrpZ1 can form oligomers, at most with 16 monomers (Haapalainen et al. 2011). Thus, at least HrpZ1 has the ability to form oligomers, probably contributing to pore formation in the host plasma membrane.

\section{Harpins as elicitors of HR cell death in apoplast of plant tissues.}

All harpins reported thus far, except XopA of Xanthomonas campestris pv. vesicatoria (Kim et al. 2004) and truncated HrpZ1 of $P$. syringae pv. tabaci (Tsunemi et al. 2011), can induce an HR in tobacco following infiltration of leaf panels (Table 1). The ability to induce an HR in tobacco plants was the first characterized function of harpins and was, in fact, how they were originally identified (He et al. 1993; Wei et al. 1992). Intensive studies on HR elicitation with several harpins revealed that certain regions of harpins are sufficient for $\mathrm{HR}$ elicitation. Mutational analysis of $\mathrm{HpaG}$ of $X$. axonopodis pv. glycines showed that the 12 amino acid (aa) residues between Leu-39 and Leu-50 is critical to HR elicitation in tobacco (Kim et al. 2004). Interestingly, XopA of X. campestris pv. vesicatoria lacks HR-eliciting activity but site-directed mutagenesis of Phe48 to Leu48 in XopA restored its HR-eliciting activity (Kim et al. 2004). HrpZ1 of P. syringae pv. phaseolicola consists of nine helices as its secondary structure, and series of peptides designed from each helix were tested for HR elicitation in tobacco (Haapalainen et al. 2011). Based on this analysis, the peptide containing helix VIII (amino acids 290 to 313) was sufficient for HR elicitation. The further fine domain mapping for HR elicitation revealed that the 16-aa region between Asp-293 and Glu-307 was sufficient for HR elicitation. In addition, deletion analysis with $\mathrm{HrpN}$ of $E$. pyrifoliae found the importance of the 13-aa region between Gly-102 and Thr113 on HR elicitation (Shrestha et al. 2008). These indicate that the specific amino acid regions of harpins are responsible for HR elicitation. Alignment of those regions responsible for HR elicitation revealed the putative consensus motif, which contains a high ratio of leucine (Haapalainen et al. 2011).

Although mechanisms of HR elicitation by harpins are not well understood, several suggestions have been made that are supported by experimental evidence. First, some harpins, as described above, may disturb membrane physiology, resulting in cell death. Second, HrpN may inhibit ATP synthesis by reducing mitochondrial electron transport in tobacco cells, not by the oxidative burst (Xie and Chen 2000). Moreover, treatment of Arabidopsis cells with HrpZ1 induces rapid release of cytochrome $\mathrm{C}$ from mitochondria to the cytosol, and reactive oxygen species accumulate (Krause and Durner 2004). These results indicate that both HrpN and HrpZ1 may indirectly disturb mitochondrial functions and induce mitochondrial-dependent programmed cell death in plants. Third, HrpZ1 induces HR-related genes such as Hinl and activates protein kinases such as AtMPK6 in Arabidopsis and its ortholog, SIPK, in tobacco (Desikan et al. 2001; Gopalan et al. 1996; Zhang and Klessig 2000). In addition, the lack of SIPK results in increased sensitivity to HrpZ1 (Samuel et al. 2005). Finally, extracellularly targeted HrpZ1 induces an HR in tobacco, whereas the same proteins targeted to the cytoplasm do not (Tampakaki and Panopoulos 2000). This evidence indicates that harpins must be recognized from outside plant cells for HR elicitation.

Interestingly, some harpins may act as a cell death suppressor. As mentioned above, E. amylovora was shown to produce two harpins, HrpN and HrpW. Treatment of each harpin at $200 \mathrm{nM}$ concentration in Arabidopsis suspension cells induced strong cell death but, surprisingly, infiltration of $\mathrm{HrpN}$ together with a low concentration of HrpW (200 nM HrpN and $0.2 \mathrm{nM} \mathrm{HrpW})$ failed to induce cell death (Reboutier et al. 2007). HrpW was unable to suppress cell death induced by $P$. syringae pv. phaseolicola HrpZ1. Similarly, HrpN was unable to suppress HrpW-induced cell death. These indicate that only HrpW at low concentrations can suppress HrpN-induced cell death. It is still not clear whether cell death suppression activity is unique to HrpW but it could be one reason why plants cannot immediately induce HR (or defense responses) when exposed to harpin-producing bacteria.

\section{Harpins as inducers of defense responses without $H R$ in plants.}

When harpin genes are constitutively expressed in plant cells or harpins are sprayed on plants, they confer defense responses to diverse plant pathogens, including fungi, oomycetes, bacteria, and viruses, without HR cell death. Spray treatment with HrpN of E. amylovora in Arabidopsis induced expression of the pathogenesis-related $(P R) 1$ gene and activated systemic acquired resistance, conferring disease resistance to Hyaloperonospora arabidopsidis (previously named Peronospora parasitica) and $P$. syringae pv. tomato (Dong et al. 1999). Foliar application of $\mathrm{HrpN}$ in tomato reduced diseases caused by Phytophthora infestans and Botrytis cinerea (Fontanilla et al. $2005 \mathrm{a}$ and $\mathrm{b}$ ). In addition, transgenic tobacco expressing the 
$h r p N$ gene showed enhanced disease resistance to $B$. cinerea (Jang et al. 2006). Similarly, establishment of disease resistance mediated by HrpN, derived from E. amylovora, E. pyrifoliae, and E. carotovora, is dependent on salicylic acid as well as jasmonic acid and ethylene, as assessed by gene expression patterns in tomato, Arabidopsis, and tobacco (Chuang et al. 2010; Dong et al. 2004; Kariola et al. 2003; Sohn et al. 2007).

In addition to HrpN, $X$. oryzae Hpa1, R. solanacearum PopA1 and PopW, and P. syringae HrpZ1 were shown to enhance plant disease resistance. Expression of hpal in tobacco induced expression of defense-related genes such as $P R-1 a$ and $P R-1 b$ in an NPR1-dependent manner without an HR phenotype (Peng et al. 2004). In addition, foliar application of the full-length Hpa1 and, particularly, $\mathrm{Hpa}_{10-42}$ fragment induced strong resistance in rice to $X$. oryzae pv. oryzae and Magnaporthe grisea in greenhouse and field conditions (Chen et al. 2008a and b). Similarly, the transgenic rice expressing hpal showed resistance to $M$. grisea (Choi et al. 2012; Shao et al. 2008). Recently, transcriptome analysis after hpal expression in cotton showed that genes responsible for multiple defense signaling pathways are constitutively expressed (Miao et al. 2010). In the case of PopA1, this protein was accumulated at pathogen infection sites and conferred resistance to oomycete Phytophthora parasitica via salicylic-acid-dependent pathways when it was expressed under a pathogen-inducible promoter (Belbahri et al. 2001). Foliar application of PopW induced resistance to Tobacco mosaic virus ( $\mathrm{Li}$ et al. 2011). Transgenic Nicotiana benthamiana and sugar beet, expressing HrpZ1 fused with PR1 signal peptide, showed enhanced resistance to Beet necrotic yellow vein virus (Pavli et al. 2011). These findings indicate that diverse harpins can trigger defense responses without HR cell death at the lower concentration or when they are retained inside plant cells.

Harpins have the ability to enhance resistance to not only plant pathogens but also insects. In Arabidopsis, treatment of HrpN of E. amylovora increased resistance to aphids (Dong et al. 2004). Seven days after infestation, the total number of aphids on HrpN-treated Arabidopsis was one-third that on buffer-treated Arabidopsis. Aphid numbers were similar in the wild-type, nprl-1, and jarl-1 mutants after harpin treatment, while the number was significantly higher in both etrl-1 and ethylene insensitive (ein) 2-1 mutants, indicating that the ethylene-signaling pathway may be involved in aphid resistance induced by treatment with HrpN (Dong et al. 2004). In Arabidopsis, 37 ethylene-inducible transcription factor genes differentially responded to E. amylovora $\mathrm{HrpN}$, and separate mutations in 9 of these genes, including AtMYB44, resulted in increased susceptibility to green peach aphid (Liu et al. 2010). It was shown that AtMYB44 regulated EIN2 expression induced by HrpN (Liu et al. 2011). These results indicate that harpin treatment increases defenses against insects through ethylenedependent pathways in plants.

\section{Harpins as plant growth enhancers.}

In addition to induction of HR and defense responses, harpins can also stimulate plant growth. Spray treatment of Arabidopsis seedlings or soaking the seed in solution containing E. amylovora HrpN enhanced seedling growth (Dong et al. 2004). This growth enhancement was still induced in both nprl-1 and jarl-1 mutants but not in etr $1-1$ and ein 5-1 mutants, indicating that the ethylene-dependent signaling pathways are involved in enhanced plant growth in response to treatment with HrpN. Transcriptome analysis in tomato after harpin treatment revealed many upregulated genes, including the SlERF5 gene encoding tomato ethylene-responsive factor 5 (Chuang et al. 2010). Interestingly, overexpression of this gene in Arabidopsis enhanced root growth, indicating that HrpN-mediated growth enhancement requires ethylene-signaling pathways. Transgenic $N$. ben- thamiana and sugar beet, expressing HrpZ1 fused with the PR1 signal peptide, grew faster (Pavli et al. 2011). In addition, the soil bacterium Bacillus thuringiensis SFC24 was shown to carry the ability to promote growth of groundnut, and the same bacterium expressing hrpZl of $P$. syringae pv. syringae enhanced growth an additional 20\% (Anil and Podile 2012). These indicate that extracellularly localized harpins can enhance plant growth through ethylene-dependent signaling pathways.

The $X$. oryzae pv. oryzicola Hpal also was shown to enhance grain yield as well as plant growth. Foliar application of this protein in rice enhanced growth and grain yield. The Hpa1 fragment encompassing the 10- to 42-aa region showed the greatest effect on growth and grain yield in both greenhouse and field conditions (Chen et al. 2008a and b). Surprisingly, this region was responsible for induction of defense response, as described above. This is probably due to induction of ethylene-dependent signaling pathways.

\section{Insights on host targets of harpins in plants.}

Despite the many beneficial functions of harpins in plants, as described above, their host targets have not been well characterized. However, there is evidence that host targets may be present in the plasma membrane. Radioisotope-labeled HrpZ1 of $P$. syringae pv. phaseolicola was found to bind to the tobacco membrane, and this binding was closely correlated with induction of defense marker gene expression (Lee et al. 2001a). HrpN-interacting protein from Malus spp. (HIPM) and its orthologs, AtHIPM in Arabidopsis and OsHIPM in rice, were found as host proteins interacting with E. amylovora $\mathrm{HrpN}$ in the yeast two-hybrid assay (Oh and Beer 2007). These proteins were also localized to the plasma membrane. More importantly, the AtHIPM mutant of Arabidopsis showed an enhanced growth phenotype, which was similar to the phenotype displayed by the wild-type plant sprayed with $\mathrm{HrpN}$, consistent with HrpN-dependent plant growth enhancement being regulated by HIPM.

Based on the effects of harpin treatments, they may be able to function both outside and inside of plant cells. The fact that infiltration of harpins into the apoplast triggers HR and spraying harpin at lower levels induces defense responses without HR or enhances plant growth indicates that harpins act outside of the plant cells. In these cases, putative target proteins of harpins are likely present in the plasma membrane. However, because ectopic expression of harpins in plant cells also can induce defense responses without HR, as described above, putative target proteins must be localized inside cells. Therefore, determination of host target proteins will help us fully understand the mechanisms of harpin functions in plants.

\section{Other putative roles of harpins.}

The attachment of plant-pathogenic bacteria on the plant surface is the first step for disease development. HrpN of $D$. dadantii was shown to be involved in efficient attachment of this bacterium on the plant surface by comparison between the wild type and the $h r p N$ mutant (Yap et al. 2006). In addition, this harpin was also involved in the formation of pellicle in the liquid medium, which is a bacterial cell aggregate similar to biofilm. In addition, several harpins (X. axonopodis pv. glycines $\mathrm{HpaG}$, E. amylovora HrpN, and P. syringae pv. syringae HrpZ1) were shown to be able to form fibril structures under apoplastlike conditions (Oh et al. 2007b). These features might be another role of harpins at the initial stage of interaction with plant cells in the apoplastic space.

\section{Future perspectives.}

Harpins are unique and multifunctional proteins that play critical roles in the interactions between bacterial pathogens 
and plants. Harpins also trigger diverse beneficial responses when sprayed or expressed in plants. Although diverse functions of harpins have been identified, how they have these effects on plants remains to be determined.

First, what are the relationships between harpins and other translocator proteins such as HrpK1? Although harpins contribute to effector translocation, a polymutant of $P$. syringae in which $h r p K l$ and four known harpin genes were deleted, retained some virulence, and a significant amount of effector proteins were still translocated (Kvitko et al. 2007), indicating that there may be other translocator proteins still functional. If so, their identities need to be determined.

Second, is there any specificity between harpins and other translocators in terms of effector translocation? As discussed, harpins might form translocator complexes with other translocator proteins. How is each translocator complex connected with Hrp pilus in vivo and how does it regulate effector proteins? These questions will help us understand the interface between bacterial pathogens and plant cells.

Third, how do harpins elicit diverse responses in plants? In addition to HR, defense responses, and growth enhancement, harpins were recently shown to increase drought tolerance in rice (Zhang et al. 2011). Are there specific host targets to regulate each response in plants? If any targets are present, what they are doing and where they are acting will be important questions to answer.

Fourth, what is the biological significance of glycine richness and lack of cysteine in harpins? Due to these features of harpins, it is generally considered that the structures of harpins are very flexible, and this flexibility might be one explanation for why harpins can be involved in diverse responses in plants.

Finally, should harpins be considered as apoplastic effectors, pathogen-associated molecular patterns (PAMPs), or both? Harpins are secreted through T3SS and trigger defense responses and HR cell death like effectors. At the same time, harpins are very abundant proteins (Nissinen et al. 2007) and can induce expression of marker genes and callose deposition like PAMPs (Boureau et al. 2011; He et al. 2006). Further studies on the molecular mechanism of harpin functions will shed much needed light on the roles that harpins play in plant-microbe interactions.

\section{ACKNOWLEDGMENTS}

This work was supported by the National Research Foundation of Korea (NRF) grant funded by the Korean Government (NRF-2011-0012016) and also "Cooperative Research Program for Agriculture Science and Technology Development (Project Number PJ00932602)", Rural Development Administration, Republic of Korea, to C.-S. Oh.

\section{LITERATURE CITED}

Alfano, J. R., and Collmer, A. 2004. Type III secretion system effector proteins: Double agents in bacterial disease and plant defense. Annu. Rev. Phytopathol. 42:385-414.

Anil, K., and Podile, A. R. 2012. HarpinPss-mediated enhancement in growth and biological control of late leaf spot in groundnut by a chlorothalonil-tolerant Bacillus thuringiensis SFC24. Microbiol. Res. 167:194198

Arlat, M., Van Gijsegem, F., Huet, J. C., Pernollet, J. C., and Boucher, C. A. 1994. PopA1, a protein which induces a hypersensitivity-like response on specific Petunia genotypes, is secreted via the Hrp pathway of Pseudomonas solanacearum. EMBO (Eur. Mol. Biol. Organ.) J. 13:543-553.

Barny, M. A. 1995. Erwinia amylovora hrpN mutants, blocked in harpin synthesis, express a reduced virulence on host plants and elicit variable hypersensitive reactions on tobacco. Eur. J. Plant Pathol. 101:333-340.

Bauer, D. W., Wei, Z.-M., Beer, S. V., and Collmer, A. 1995. Erwinia chrysanthemi harpin ${ }_{E c h}$ : An elicitor of the hypersensitive response that contributes to soft-rot pathogenesis. Mol. Plant-Microbe Interact. 8:484-491.
Belbahri, L., Boucher, C., Candresse, T., Nicole, M., Ricci, P., and Keller, H. 2001. A local accumulation of the Ralstonia solanacearum PopA protein in transgenic tobacco renders a compatible plant-pathogen interaction incompatible. Plant J. 28:419-430.

Bocsanczy, A. M., Nissinen, R. M., Oh, C.-S., and Beer, S. V. 2008. HrpN of Erwinia amylovora functions in the translocation of DspA/E into plant cells. Mol. Plant Pathol. 9:425-434.

Bogdanove, A. J., Beer, S. V., Bonas, U., Boucher, C. A., Collmer, A. Coplin, D. L., Cornelis, G. R., Huang, H.-C., Hutcheson, S. W., Panopoulos, N. J., and Van Gijsegem, F. 1996a. Unified nomenclature for broadly conserved hrp genes of phytopathogenic bacteria. Mol. Microbiol. 20:681-683.

Bogdanove, A. J., Wei, Z.-M., Zhao, L., and Beer, S. V. 1996b. Erwinia amylovora secretes harpin via a type III pathway and contains a homo$\log$ of yopN of Yersinia. J. Bacteriol. 178:1720-1730.

Boureau, T., Siamer, S., Perino, C., Gaubert, S., Patrit, O., Degrave, A. Fagard, M., Chevreau, E., and Barny, M. A. 2011. The HrpN effector of Erwinia amylovora, which is involved in type III translocation, contributes directly or indirectly to callose elicitation on apple leaves. Mol Plant-Microbe Interact. 24:577-584.

Charkowski, A. O., Alfano, J. R., Preston, G., Yuan, J., He, S. Y., and Collmer, A. 1998. The Pseudomonas syringae pv. tomato HrpW protein has domains similar to harpins and pectate lyases and can elicit the plant hypersensitive response and bind to pectate. J. Bacteriol. 180:5211-5217.

Chen, L., Qian, J., Qu, S., Long, J., Yin, Q., Zhang, C., Wu, X., Sun, F., Wu, T., Hayes, M., Beer, S. V., and Dong, H. 2008a. Identification of specific fragments of HpaG Xooc, a harpin from Xanthomonas oryzae pv. oryzicola, that induce disease resistance and enhance growth in plants. Phytopathology 98:781-791.

Chen, L., Zhang, S. J., Zhang, S. S., Qu, S., Ren, X., Long, J., Yin, Q., Qian, J., Sun, F., Zhang, C., Wang, L., Wu, X., Wu, T., Zhang, Z., Cheng, Z., Hayes, M., Beer, S. V., and Dong, H. 2008b. A fragment of the Xanthomonas oryzae pv. oryzicola harpin HpaG Xooc reduces disease and increases yield of rice in extensive grower plantings. Phytopathology 98:792-802.

Choi, M.-S., Heu, S., Pack, N.-C., Koh, H.-J., Lee, J.-S., and Oh, C.-S 2012. Ectopic expression of hpal gene of Xanthomonas oryzae pv. oryzae encoding a bacterial harpin protein enhances disease resistance to both fungal and bacterial pathogens in rice and Arabidopsis. Plant Pathol. J. 28:364-372.

Chuang, H., Harnrak, A., Chen, Y.-C., and Hsu, C.-M. 2010. A harpininduced ethylene-responsive factor regulates plant growth and responses to biotic and abiotic stresses. Biochem. Biophys. Res. Commun. 402:414-420.

Crabill, E., Karpisek, A., and Alfano, J. R. 2012. The Pseudomonas syringae HrpJ protein controls the secretion of type III translocator proteins and has a virulence role inside plant cells. Mol. Microbiol. 85:225-238.

Desikan, R., Hancock, J. T., Ichimura, K., Shinozaki, K., and Neill, S. J. 2001. Harpin induces activation of the Arabidopsis mitogen-activated protein kinases AtMPK4 and AtMPK6. Plant Physiol. 126:1579-1587.

Dong, H., Delaney, T. P., Bauer, D. W., and Beer, S. V. 1999. Harpin induces disease resistance in Arabidopsis through the systemic acquired resistance pathway mediated by salicylic acid and the NIM1 gene. Plant J. 20:207-215.

Dong, H. P., Peng, J., Bao, Z., Meng, X., Bonasera, J. M., Chen, G., Beer, S. V., and Dong, H. 2004. Downstream divergence of the ethylene signaling pathway for harpin-stimulated Arabidopsis growth and insect defense. Plant Physiol. 136:3628-3638.

Eitas, T. K., and Dangl, J. L. 2010. NB-LRR proteins: Pairs, pieces, perception, partners, and pathways. Curr. Opin. Plant Biol. 13:472-477.

Engelhardt, S., Lee, J., Gabler, Y., Kemmerling, B., Haapalainen, M. L. Li, C.-M., Wei, Z., Keller, H., Joosten, M., Taira, S., and Nurnberger, T. 2009. Separable roles of the Pseudomonas syringae pv. phaseolicola accessory protein HrpZ1 in ion-conducting pore formation and activation of plant immunity. Plant J. 57:706-717.

Fauvart, M., Verstraeten, N., Dombrecht, B., Venmans, R., Beullens, S. Heusdens, C., and Michiels, J. 2009. Rhizobium etli HrpW is a pectindegrading enzyme and differs from phytopathogenic homologues in enzymically crucial tryptophan and glycine residues. Microbiology 155:3045-3054.

Fontanilla, J. M., Montes, M., and De Prado, R. 2005a. Induction of resistance to the pathogenic agent Botrytis cinerea in the cultivation of the tomato by means of the application of the protein "Harpin" (Messenger). Commun. Agric. Appl. Biol. Sci. 70:35-40.

Fontanilla, J. M., Montes, M., and De Prado, R. 2005b. Effects of the foliar-applied protein "Harpin(Ea)" (messenger) on tomatoes infected with Phytophthora infestans. Commun. Agric. Appl. Biol. Sci. 70:41-45.

Fouts, D. E., Abramovitch, R. B., Alfano, J. R., Baldo, A. M., Buell, C.R., Cartinhour, S., Chatterjee, A. K., D’Ascenzo, M., Gwinn, M. L., 
Lazarowitz, S. G., Lin, N. C., Martin, G. B., Rehm, A. H., Schneider, D. J., van Dijk, K., Tang, X., and Collmer, A. 2002. Genomewide identification of Pseudomonas syringae pv. tomato DC3000 promoters controlled by the HrpL alternative sigma factor. Proc. Natl. Acad. Sci. U.S.A. 99:2275-2280.

Fu, Z. Q., Guo, M., and Alfano, J. R. 2006. Pseudomonas syringae HrpJ is a type III secreted protein that is required for plant pathogenesis, injection of effectors, and secretion of the HrpZ1 Harpin. J. Bacteriol. 188:6060-6069.

Gaudriault, S., Brisset, M. N., and Barny, M. A. 1998. HrpW of Erwinia amylovora, a new Hrp-secreted protein. FEBS (Fed. Eur. Biochem. Soc.) Lett. 428:224-228.

Gopalan, S., Wei, W., and He, S. Y. 1996. Hrp Gene-dependent induction of hin 1: A plant gene activated rapidly by both harpins and the avrPto gene-mediated signal. Plant J. 10:591-600.

Grant, S. R., Fisher, E. J., Chang, J. H., Mole, B. M., and Dangl, J. L. 2006. Subterfuge and manipulation: Type III effector proteins of phytopathogenic bacteria. Annu. Rev. Microbiol. 60:425.

Haapalainen, M., Engelhardt, S., Kufner, I., Li, C.-M., Nurnberger, T., Lee, J., Romantschuk, M., and Taira, S. 2011. Functional mapping of harpin HrpZ of Pseudomonas syringae reveals the sites responsible for protein oligomerization, lipid interactions and plant defence induction. Mol. Plant Pathol. 12:151-166.

He, P., Shan, L., Lin, N. C., Martin, G. B., Kemmerling, B., Nurnberger, T., and Sheen, J. 2006. Specific bacterial suppressors of MAMP signaling upstream of MAPKKK in Arabidopsis innate immunity. Cell 125:563575

He, S. Y., Huang, H.-C., and Collmer, A. 1993. Pseudomonas syringae pv. syringae harpin ${ }_{\mathrm{Pss}}$ : A protein that is secreted via the Hrp pathway and elicits the hypersensitive response in plants. Cell 73:1255-1266.

Jang, Y. S., Sohn, S. I., and Wang, M. H. 2006. The hrpN gene of Erwinia amylovora stimulates tobacco growth and enhances resistance to Botrytis cinerea. Planta 223:449-456.

Jin, Q., and He, S.Y. 2001. Role of the Hrp pilus in type III protein secretion in Pseudomonas syringae. Science 294:2556-2558.

Kariola, T., Palomaki, T. A., Brader, G., and Palva, E. T. 2003. Erwinia carotovora subsp. carotovora and Erwinia-derived elicitors HrpN and PehA trigger distinct but interacting defense responses and cell death in Arabidopsis. Mol. Plant-Microbe Interact. 16:179-187.

Kim, J. F., and Beer, S. V. 1998. HrpW of Erwinia amylovora, a new harpin that contains a domain homologous to pectate lyases of a distinct class. J. Bacteriol. 180:5203-5210.

Kim, J. G., Park, B. K., Yoo, C. H., Jeon, E., Oh, J., and Hwang, I. 2003. Characterization of the Xanthomonas axonopodis pv. glycines Hrp pathogenicity island. J. Bacteriol. 185:3155-3166.

Kim, J. G., Jeon, E., Oh, J., Moon, J. S., and Hwang, I. 2004. Mutational analysis of Xanthomonas harpin HpaG identifies a key functional region that elicits the hypersensitive response in nonhost plants. J. Bacteriol. 186:6239-6247.

Krause, M., and Durner, J. 2004. Harpin inactivates mitochondria in Arabidopsis suspension cells. Mol. Plant-Microbe Interact. 17:131-139.

Kvitko, B. H., Ramos, A. R., Morello, J. E., Oh, H.-S., and Collmer, A. 2007. Identification of harpins in Pseudomonas syringae pv. tomato DC3000, which are functionally similar to HrpK1 in promoting translocation of type III secretion system effectors. J. Bacteriol. 189:80598072

Lee, J., Klessig, D. F., and Nurnberger, T. 2001a. A harpin binding site in tobacco plasma membranes mediates activation of the pathogenesisrelated gene HINI independent of extracellular calcium but dependent on mitogen-activated protein kinase activity. Plant Cell 13:1079-1093.

Lee, J., Klusener, B., Tsiamis, G., Stevens, C., Neyt, C., Tampakaki, A. P., Panopoulos, N. J., Noller, J., Weiler, E. W., Cornelis, G. R., Mansfield, J. W., and Nurnberger, T. 2001b. HrpZ(Psph) from the plant pathogen Pseudomonas syringae pv. phaseolicola binds to lipid bilayers and forms an ion-conducting pore in vitro. Proc. Natl. Acad. Sci. U.S.A. 98:289-294

Li, C. M., Brown, I., Mansfield, J., Stevens, C., Boureau, T., Romantschuk, M., and Taira, S. 2002. The Hrp pilus of Pseudomonas syringae elongates from its tip and acts as a conduit for translocation of the effector protein HrpZ. EMBO (Eur. Mol. Biol. Organ.) J. 21:1909-1915.

Li, J. G., Liu, H. X., Cao, J., Chen, L. F., Gu, C., Allen, C., and Guo, J. H. 2010. PopW of Ralstonia solanacearum, a new two-domain harpin targeting the plant cell wall. Mol. Plant Pathol. 11:371-381.

Li, J. G., Cao, J., Sun, F. F., Niu, D. D., Yan, F., Liu, H. X., and Guo, J. H. 2011. Control of Tobacco mosaic virus by PopW as a result of induced resistance in tobacco under greenhouse and field conditions. Phytopathology 101:1202-1208.

Liu, R., Lu, B., Wang, X., Zhang, C., Zhang, S., Qian, J., Chen, L., Shi, H., and Dong, H. 2010. Thirty-seven transcription factor genes differentially respond to a harpin protein and affect resistance to the green peach aphid in Arabidopsis. J. Biosci. 35:435-450.

Liu, R., Chen, L., Jia, Z., Lu, B., Shi, H., Shao, W., and Dong, H. 2011. Transcription factor AtMYB44 regulates induced expression of the ETHYLENE INSENSITIVE2 gene in Arabidopsis responding to a harpin protein. Mol. Plant-Microbe Interact. 24:377-389.

Miao, W., Wang, X., Song, C., Wang, Y., Ren, Y., and Wang, J. 2010. Transcriptome analysis of $\mathrm{Hpa}_{\mathrm{Xoo}}$ transformed cotton revealed constitutive expression of genes in multiple signaling pathways related to disease resistance. J. Exp. Bot. 61:4263-4275.

Montagner, C., Arquint, C., and Cornelis, G. R. 2011. Translocators YopB and YopD from Yersinia enterocolitica form a multimeric integral membrane complex in eukaryotic cell membranes. J. Bacteriol. 193:69236928.

Neyt, C., and Cornelis, G. R. 1999. Insertion of a Yop translocation pore into the macrophage plasma membrane by Yersinia enterocolitica: Requirement for translocators YopB and YopD, but not LcrG. Mol. Microbiol. 33:971-981.

Nissinen, R. M., Ytterberg, A. J., Bogdanove, A. J., Van Wijk, K. J., and Beer, S. V. 2007. Analyses of the secretomes of Erwinia amylovora and selected hrp mutants reveal novel type III secreted proteins and an effect of HrpJ on extracellular harpin levels. Mol. Plant Pathol. 8:55-67.

Noel, L., Thieme, F., Nennstiel, D., and Bonas, U. 2002. Two novel type III-secreted proteins of Xanthomonas campestris pv. vesicatoria are encoded within the hrp pathogenicity island. J. Bacteriol. 184:13401348.

Oh, C.-S., and Beer, S. V. 2007. AtHIPM, an ortholog of the apple HrpNinteracting protein, is a negative regulator of plant growth and mediates the growth-enhancing effect of $\mathrm{HrpN}$ in Arabidopsis. Plant Physiol. $145: 426-436$

Oh, H.-S., Kvitko, B. H., Morello, J. E., and Collmer, A. 2007a. Pseudomonas syringae lytic transglycosylases coregulated with the type III secretion system contribute to the translocation of effector proteins into plant cells. J. Bacteriol. 189:8277-8289.

Oh, J., Kim, J.-G., Jeon, E., Yoo, C.-H., Moon, J. S., Rhee, S., and Hwang, I. 2007b. Amyloidogenesis of type III-dependent harpins from plant pathogenic bacteria. J. Biol. Chem. 282:13601-13609.

Pavli, O. I., Kelaidi, G. I., Tampakaki, A. P., and Skaracis, G. N. 2011. The hrpZ gene of Pseudomonas syringae pv. phaseolicola enhances resistance to rhizomania disease in transgenic Nicotiana benthamiana and sugar beet. PLoS One 6:e17306.

Peng, J. L., Bao, Z. L., Ren, H. Y., Wang, J. S., and Dong, H. S. 2004. Expression of harpin(xoo) in transgenic tobacco induces pathogen defense in the absence of hypersensitive cell death. Phytopathology 94:10481055.

Petnicki-Ocwieja, T., van Dijk, K., and Alfano, J. R. 2005. The hrpK operon of Pseudomonas syringae pv. tomato DC3000 encodes two proteins secreted by the type III (Hrp) protein secretion system: HopB1 and HrpK, a putative type III translocator. J. Bacteriol. 187:649-663.

Racape, J., Belbahri, L., Engelhardt, S., Lacombe, B., Lee, J., Lochman, J., Marais, A., Nicole, M., Nurnberger, T., Parlange, F., Puverel, S., and Keller, H. 2005. Ca2+-dependent lipid binding and membrane integration of PopA, a harpin-like elicitor of the hypersensitive response in tobacco. Mol. Microbiol. 58:1406-1420.

Reboutier, D., Frankart, C., Briand, J., Biliqui, B., Rona, J. P., Haapalainen, M., Barny, M. A., and Bouteau, F. 2007. Antagonistic action of harpin proteins: HrpWea from Erwinia amylovora suppresses HrpNea-induced cell death in Arabidopsis thaliana. J. Cell Sci. 120:3271-3278.

Roine, E., Wei, W., Yuan, J., Nurmiaho-Lassila, E.-L., Kalkkinen, N., Romantschuk, M., and He, S. Y. 1997. Hrp pilus: An hrp-dependent bacterial surface appendage produced by Pseudomonas syringae pv. tomato DC3000. Proc. Nat. Acad. Sci. U.S.A. 94:3459-3464.

Samuel, M. A., Hall, H., Krzymowska, M., Drzewiecka, K., Hennig, J., and Ellis, B. E. 2005. SIPK signaling controls multiple components of harpin-induced cell death in tobacco. Plant J. 42:406-416.

Sgro, G. G., Ficarra, F. A., Dunger, G., Scarpeci, T. E., Valle, E. M., Cortadi, A., Orellano, E. G., Gottig, N., and Ottado, J. 2012. Contribution of a harpin protein from Xanthomonas axonopodis pv. citri to pathogen virulence. Mol. Plant Pathol. 13:1047-1059.

Shao, M., Wang, J., Dean, R. A., Lin, Y., Gao, X., and Hu, S. 2008. Expression of a harpin-encoding gene in rice confers durable nonspecific resistance to Magnaporthe grisea. Plant Biotechnol. J. 6:73-81.

Shrestha, R., Park, D. H., Cho, J. M., Cho, S., Wilson, C., Hwang, I., Hur, J. H., and Lim, C. K. 2008. Genetic organization of the hrp genes cluster in Erwinia pyrifoliae and characterization of HR active domains in $\mathrm{HrpN}_{\mathrm{Ep}}$ protein by mutational analysis. Mol. Cells 25:30-42.

Sinn, J. P., Oh, C.-S., Jensen, P. J., Carpenter, S. C. D., Beer, S. V., and McNellis, T. W. 2008. The C-terminal half of the HrpN virulence protein of the fire blight pathogen Erwinia amylovora is essential for its secretion and for its virulence and avirulence activities. Mol. PlantMicrobe Interact. 11:1387-1397. 
Sohn, S. I., Kim, Y. H., Kim, B. R., Lee, S. Y., Lim, C. K., Hur, J. H., and Lee, J. Y. 2007. Transgenic tobacco expressing the $h r p N(\mathrm{EP})$ gene from Erwinia pyrifoliae triggers defense responses against Botrytis cinerea. Mol. Cells 24:232-239.

Tampakaki, A. P., and Panopoulos, N. J. 2000. Elicitation of hypersensitive cell death by extracellularly targeted $\mathrm{HrpZ}_{\mathrm{Psph}}$ produced in planta. Mol. Plant-Microbe Interact. 13:1366-1374.

Tampakaki, A. P., Skandalis, N., Gazi, A. D., Bastaki, M. N., Sarris, P. F., Charova, S. N., Kokkinidis, M., and Panopoulos, N. J. 2010. Playing the "Harp": Evolution of our understanding of hrp/hrc genes. Annu. Rev. Phytopathol. 48:347-370.

Tsunemi, K., Taguchi, F., Marutani, M., Watanabe-Sugimoto, M., Inagaki, Y., Toyoda, K., Shiraishi, T., and Ichinose, Y. 2011. Degeneration of hrpZ gene in Pseudomonas syringae pv. tabaci to evade tobacco defence: An arms race between tobacco and its bacterial pathogen. Mol. Plant Pathol. 12:709-714.

Wei, Z.-M., and Beer, S. V. 1995. hrpL activates Erwinia amylovora hrp gene transcription and is a member of the ECF subfamily of $\sigma$ factors. J. Bacteriol. 177:6201-6210.

Wei, Z. M., Laby, R. J., Zumoff, C. H., Bauer, D. W., He, S. Y., Collmer, A., and Beer, S. V. 1992. Harpin, elicitor of the hypersensitive response produced by the plant pathogen Erwinia amylovora. Science 257:85-88. Xie, Z., and Chen, Z. 2000. Harpin-induced hypersensitive cell death is associated with altered mitochondrial functions in tobacco cells. Mol. Plant-Microbe Interact. 13:183-190.

Yang, C. H., Gavilanes-Ruiz, M., Okinaka, Y., Vedel, R., Berthuy, I., Boccara, M., Chen, J. W., Perna, N. T., and Keen, N. T. 2002. hrp genes of Erwinia chrysanthemi 3937 are important virulence factors. Mol. Plant-Microbe. Interact. 15:472-480

Yap, M. N., Rojas, C. M., Yang, C. H., and Charkowski, A. O. 2006. Harpin mediates cell aggregation in Erwinia chrysanthemi 3937. J. Bacteriol. 188:2280-2284.

Zhang, L., Xiao, S., Li, W., Feng, W., Li, J., Wu, Z., Gao, X., Liu, F., and Shao, M. 2011. Overexpression of a Harpin-encoding gene hrfl in rice enhances drought tolerance. J. Exp. Bot. 62:4229-4238.

Zhang, S., and Klessig, D. F. 2000. Pathogen-induced MAP kinases in tobacco. Results Probl. Cell Differ. 27:65-84.

Zhu, W., MaGbanua, M. M., and White, F. F. 2000. Identification of two novel hrp-associated genes in the hrp gene cluster of Xanthomonas oryzae pv. oryzae. J. Bacteriol. 182:1844-1853.

Zipfel, C., and Rathjen, J. P. 2008. Plant immunity: AvrPto targets the frontline. Curr. Biol. 18:R218-220. 